\title{
DIVERSIFIKASI DESAIN PRODUK SENTRA KERAMIK DINOYO BERSUMBER IDE BUDAYA LOKAL MALANG
}

\section{Ponimin}

\author{
Universitas Negeri Malang
}

\begin{abstract}
Ceramic craft in Sentra Keramik Dinoyo of Malang has been produced in more or less four generations long. In the beginning, local crafters made potteries in traditional kitchenware. The increasing demand of consumer made room for decorative ceramic. Unfortunately, their product design development didn't reflect local culture nuance. It because crafters weren't able to develop the design. Through this activity, researcher tried to solve design problem, extracted from local culture as ceramic creation idea. So that local culture could appear as local ceramic characters. Ceramic product design development is done by formulating design concept, manifesting concept into product design image. Design image result then tested to design expert. The product design image then improved. This design improvement then manifested into ceramic product prototype. This development produced a unique design, one of them is ceramic with 'Kendi Garuda Kamandalu' (teapot) from Kidal Temple's reliefs theme.
\end{abstract}

Keywords: Diversification, ceramic design, local culture.

\begin{abstract}
Abstrak: Produk Kerajinan keramik di sentra keramik Dinoyo Malang sudah dilakukan kurang lebih hampir empat generasi. Pada mulanya para perajin setempat membuat keramik gerabah berupa peralatan dapur tradisional. Karena berkembangnya tuntutan masyarakat penggunannya maka berkembang untuk barang keramik hias. Namun dalam perkembangan disain produknya tidak mencerminkan nuansa budaya lokal. Hal ini disebabkan para perajin tidak mampu untuk mengembangkan desain tersebut. Penelitian berupayah memecahkan persoalan desain yang digali dari budaya lokal sebagai ide kreasi keramik. Sehingga nuansa budaya lokal menjadi ciri khas keramik setempat. Pengembangan desain produk keramik dilakukan dengan merumuskan konsep desain, mewujudkan konsep ke dalam gambar desain produk. Hasil gambar desain dicoba ke pakar desain. Hasil uji gambar desain produk disempurnakan dan desain diwujudkan ke dalam prototipe produk karya keramik. Pengembangan ini menghasilkan keunikan desain yang salah satunya berupa keramik betema Kendi Garuda Kamandalu dari relief Candi Kidal Malang
\end{abstract}

Kata Kunci: Diversifikasi, desain keramik, budaya lokal. 
Kerajinan keramik Dinoyo merupakan hasil kegiatan budaya tradisional yang berlangsung secara turun-temurun di sentra keramik tersebut. Kegiatan ini dihasilkan oleh sekelompok masyarakat di kampung Dinoyo, yang pada mulanya merupakan kegiatan penopang kehidupan agraris. Desain produk keramik tersebut selanjutnya mengalami perubahan yang dipengaruhi kemauan, kemampuan perajin untuk melakukan perubahan. Perubahan juga didorong oleh masyarakat sebagai pengguna produk keramik. Hal ini sesuai dengan teori budaya yang dikemukakan oleh Sobur (2013), bahwa kelangsungan dan perubahan suatu kebudayaan tidak terlepas dari faktor yang melingkupi budaya tersebut. Yakni faktor produsen budaya, pengguna, dan dampak dari perubahan budaya. Faktor penentu perubahan tersebut meliputi: lembaga budaya yang berupa produsen dan pengguna produk budaya, serta dampak dari hasil produk budaya (Thompson, 2012). Produk keramik Dinoyo yang dihasilkan oleh sekelompok masyarakat perajin tidak terlepas dari faktor-faktor yang melingkupi baik secara internal/eksternal. Faktor dorongan internal dan eksternal tersebut membawa pada keunikan yang melekat baik secara fisik atau non fisik, karena dukungan dari produsen budaya dan ada tuntutan dari konsumen budaya (Becker, 2016).

Seperti halnya produk keramik Dinoyo, produk keramik Dinoyo dapat diminati oleh calon penggunanya, tentu ada faktor yang melekat secara unik, yang dibentuk oleh perajin yang dipengaruhi oleh lembaga sekitarnya, yaitu peran peneliti, konsumen, dan lembaga lain, yang peduli untuk mengenbangkan desain tersebut. Hasil pengembangan tersebut diharapkan dapat menjadi nilai keunikan pada desain keramik tersebut (Ponimin, 2015:9). Desain Produk yang selama ini digeluti tidak mencerminkan aspek budaya sebagai ide berkreasi. Oleh karena itu desain produknya tidak mencerminkan keunikan yang menggambarkan budaya lokal sebagai ide kreasi. Karena itu dirasa perlu mengembankan desain dengan menyesuaikan tuntutan konsumen dan prinsip-prinsip estetik desain produk tersebut. Rohidi (2011:45) mengemukakan bahwa, suatu produk budaya akan mengalami perubahan dengan menyesuaikan dari dengan tuntutan jamannya, maka pelaku budaya dituntut memiliki sikap inovatif dalam melakukan perubahan budaya yang diciptakan, yaitu dengan melakukan perubahan yang menyesuaikan selera estetik pada eranya. Suatu produk keramik akan bisa berlangsung apabila adanya ide-ide kreatif dari pelakunya yang didukung oleh faktor eksternal dalam memenuhi selera artistik di eranya (Guntur, 2007:75).

Agar keramik Dinoyo sebagai produk budaya estetik dapat diterima di tengah masyarakat, maka pengembangan produk tidak bisa dilepaskan dari produsen budaya (perajinnya). Dibutuhkan lembaga budaya lain di luar produsen budaya (termasuk peneliti akademisi) untuk turut andil memikirkan dan menyumbangkan aksinya. Dalam teori budaya terdapat 3 lembaga budaya penting yang tidak dapat dilepaskan sebagai penopang kelangsungan budaya, yakni: lembaga produsen budaya. Yakni meliputi pengrajin keramik dan lembaga akademisi sebagai penopang peningkatan teknologi, serta konsumen sebagai pengguna produk, yang selalu menuntut perubahan trend estetik. Oleh karena itu peneliti yang telah melakukan studi awal turut andil memecahkan persoalan yang dihadapi oleh pengrajin sebagai produsen budaya. Berkaitan dengan hal tersebut, peneliti melibatkan diri dalam memecahkan persoalan estetik melalui solusi diverifikasi produk (Herawati, 2015:301).

Berdasarkan hasil pengamatan di lapangan oleh peneliti berkesimpulan terdapat kelemahan desain pada produk keramik Dinoyo. Tuntutan selera pengguna estetik desain produk keramik telah mengalami perubahan yang didorong kondisi lingkungan. Sebagai masyarakat yang hidup di lingkungan budaya urban, sementara mereka mayoritas juga tidak dapat terlepas dengan nilai-nilai kelokalan (Bayindir, 2015:2874). Sebagai contoh, 
bahwa pengguna keramik Dinoyo kebanyakan adalah menghuni rumah tinggal dengan corak arsitektur yang interior bergaya minimalis. Kehidupan mereka tidak dapat terlepaskan dari budaya masa lalu yang melingkupi, sehingga pada umumnya mereka membutuhkan elemen-elemen estetik dengan menyesuaikan kepentingan estetik yang serasi dengan tatanan interior rumah tinggal mereka (Elnur Latif, 2015:21).

Hasil pengamatan dari lapangan tersebut dapat sebagai dasar pijakan peneliti penciptaan seni untuk mengembangkan desain keramik Dinoyo dengan tindakan kreatif yang dilakukan melalui perencanaan yang matang. Tahap pengembangan dimulai dengan merumuskan konsep diversifikasi desain produk dan menyusun tahapan mewujudkan konsep menjadi karya desain, yang menitikberatkan pada sumber ide budaya lokal Indonesia sebagai ide dasar berkreasi.

\section{METODE}

Penelitian dan penciptaan seni ini bertujuan menghasikan pengembangan desain produk keramik. Pengembangan dimulai dengan memangun konsep untuk dasar pengembangan bentuk produk. Yakni pengembangan desain produk keramik yang bersumber pada budaya lokal, utamanya dari relief Kendi Kamandalu Candi Kidal Malang. Metode pendekatan yang digunakan adalah pendekatan kreatif yang mengacu pada prinsipprinsip pengembangan desain produk. Dalam pengembangan desain, kreator desain (desainer), perlu mempertimbangkan berbagai hal yang mengacu pada kepentingan publik dan kepentingan artistik. Seni kerajinan untuk kepentingan publik diciptakan dengen mempertimbangkan berbagai hal yang berprinsip pada aspek artistik, psikologis, ergonomis, kepraktisan, keamanan, kenyamanan, ekonomis, simbolik, dan filosofis. Oleh karena itu dibutuhkan serangkaian proses dalam menghasilkan produk kreatif tersebut dengan mempertimbangkan kebutuhan publik (Sonny Kartika, 2015:125).

Untuk mencapai hasil tersebut perlu ditetapkan metode penelitian penciptaan yang dapat menghasilkan luaran penelitian. Metode tersebut di antaranya berupa tahapan penelitian. Antara lain tahapan; (a) melakukan kajian ragam budaya lokal khususnya di kawasan Malang yang berpotensi untuk dikembangkan ke dalam desain produk keramik Dinoyo, (b) merumuskan konsep pengembangan desain keramik Dinoyo bernuansa budaya lokal, (c) proses pengembangan desain produk keramik yang meliputi: eksplorasi visual berbentuk gambar sketsa karya keramik. Tahapan tersebut berupa gambar pradesain atau sketsa alternatif berbagai bentuk, ornamen, fungsi, dan demensi karya keramik, serta eksplorasi berbagai teknik pembentukan dan pembakaran, (d) pembentukan karya keramik bernuansa budaya lokal, (e) Pengujian dan evaluasi hasil pengembangan desain keramik Dinoyo, (f) Penyempurnaan hasil pengembangan konsep dan desain produk keramik sentra kerajinan keramik Dinoyo bernuansa budaya lokal (Finlay, 2009:55). Tahapan penelitian dapat diamati melalui skema sebagai berikut: 
Hasil penggalian data di lapangan, desain produk keramik Dinoyo perlu dikembangkan dengan mengangkat budaya lokal sebagai ide diversifikasi desain produk.

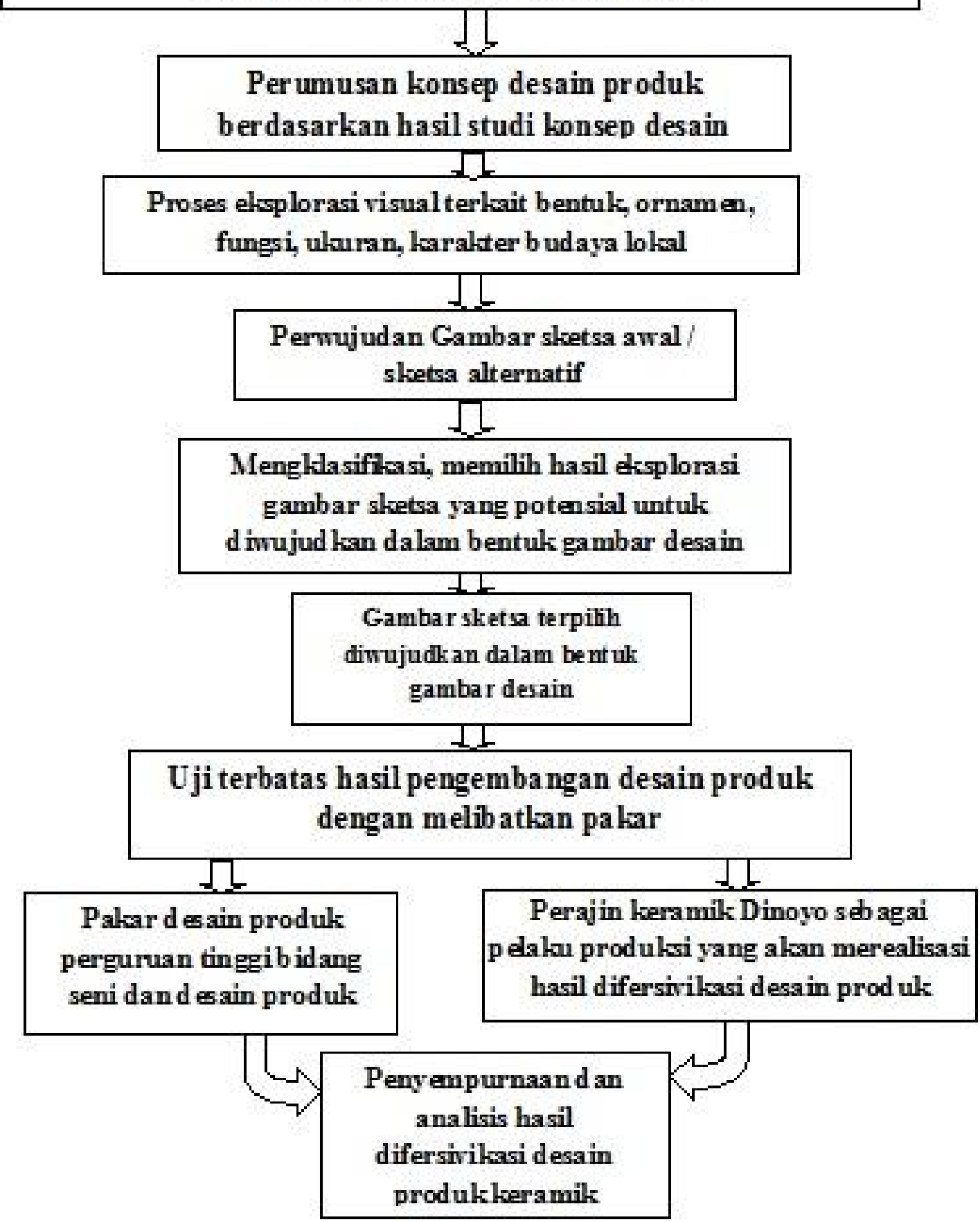

Gambar skema alur proses penelitian diversifikasi desain produk keramik Dinoyo yang dikembangkan dari (Kartika Sony, 2015). 


\section{HASIL DAN PEMBAHASAN}

\section{Data Desain Produk Keramik Dinoyo}

Desain produk keramik yang dihasilkan para perajin di sentra keramik Dinoyo Malang Indonesia selama ini lebih berorientasi pada pemenuhan kebutuhan sehari-hari berupa barang fungsional praktis dan elemen estetik interior. Hasil observasi juga menunjukKan bahwa desain produk tersebut juga tidak mengolah unsur budaya lokal sebagai ide kreasi bentuk maupun ragam hiasnya (observasi 23- 26 Januari 2017).

Hasil pengamatan di lapangan menunjukan, desain keramik Dinoyo ditinjau dari segi fungsional dan artistik, bahwa desain produk tersebut diciptakan terdiri dari beragam bentuk, ornamen, dan fungsi yang masih bersifat konvensional. Oleh karena itu diperlukan pengembangan desain terhadap produk keramik di sentra kerajinan tersebut. Pengembangan desain dengan melakukan reinovasi desain produk. Tindakan ini diharapkan dapat memperkaya ragam desainnya, sehingga dapat memenuhi tuntutan pasar yang semakin berkembang. Era perkembangan budaya global menuntut diversifikasi desain produk keramik yang tidak hanya untuk mencapai tujuan finansial semata (Julia, 2011:2). Akan tetapi pentingnya unsur budaya lokal sebagai ide bentuk maupun ragam hias dengan melakukan reinovasi budaya lokal tersebut ke dalam wujud karya keramik. Dengan demikian hasil pengembangan desain produk desain keramik memiliki keunikan atau kekhasan bentuk maupun ornamen yang melekat pada bentuk tersebut, yakni dengan mengangkat ragam unsur bentuk budaya lokal untuk dideformasi ke dalam bentuk karya keramik maupun ragam hiasnya (Reijnders A., 2005: 22).

Tahapan awal untuk diversifikasi desain produk tersebut dengan pengkajian budaya lokal terpilih. Unsur budaya yang dipilih sebagai ide pendorong potensi kreatif peneliti. Potensi-potensi kreatif muncul melalui imajinasi yang dipicuh sumber ide budaya lokal terpilih tersebut. Selanjutnya diolah menjadi konsep penciptaan. Dari konsep penciptaan ini di antaranyaberisi tentang konsep rencana bentuk-bentuk maupun ornamen karya keramik. Merujuk pada pendapat Marianto, M. Dwi, (2015:55), bahwa ide kreatif yang didorong imajinasi estetik peneliti, selanjutnya diolah menjadi konsep bentuk karya. Hal ini merupakan tindakan dalam proses kreatif yang dikuatkan oleh pengalaman peneliti dalam menggeluti bidang kriya, terutama dalam kerajian keramik. Selanjutnya potensi kreatif yang diolah menjadi rencana berkarya, dan dirumuskan menjadi konsep penciptaan karya desain produk keramik Dinoyo. Konsep penciptaan tersebut sebagai pedoman dalam proses reinovasi desain keramik Dinoyo ke dalam bentuk visual.

Berdasarkan hasil seleksi unsur budaya lokal yang diolah menjadi ide desain produk, diantaranya mengolah sumber ide pengembangan desain produk keramik Dinoyo berupa relief Garuda Kamandalu di candi Kidal. Hasil pengkajian dari budaya tersebut digunakan sebagai ide inspirasi rumusan konsep bentuk karya. Merujuk pada pemikiran Sachari, (2005:93), konsep bentuk karya merupakan susunan elemen visual yang mempertimbangkan prinsip-prinsip desain ke dalam fungsi benda hias dan dan benda pakai. Hasil rumusan konsep karya dikembangkan untuk pedoman mengolah bentuk rencana karya. Pengolahan bentuk karya dilakukan dengan berbagai eksplorasi bentuk, yakni berupa berbagai ragam gambar sketsa alternatif. 


\section{Diversifikasi Desain produk keramik bersumber ide relief "K endi $G$ aruda Kamandalu Candi Kidal".}

Proses diversifikasi desain produk yang bersumber budaya lokal menghasilkan desain produk keramik yang bertema sebagai berikut: karya desain produk keramik yang digali dan diolah dari relief Candi Kidal Tumpang Malang berupa karya guci atau kendi hias berjudul "Kendi Garuda Kamandalu". Karya desain produk keramik ini terinspirasi dari cerita burung Garuda yang sedang membebaskan ibunya dari perbudakan. Relief tentang pembebasan dari perbudakan terletak pada kaki candi Kidal. Relief tersebut berbentuk burung Garuda sedang memanggul guci Amerta (wadah pancuran air). Burung Garuda sebagai putra Dewi Winata sedang membebaskan ibunya yang diperbudak saudaranya sendiri yaitu Dewi Kadru. Dewi Kadru merupakan ibu para ular dan naga. Dewi Winata dapat dibebaskan, namun ada permintaan dari dewi Kadru asalkan Garuda dapat membawah pulang Guci Amerta. Akhirnya burung Garuda menolak permintaan tersebut. Terjadilah peperangan antara burung Garuda dan ular, putra dari dewi Kadru. Peperangan tersebut dimenangkan oleh burung Garuda karena dibantu oleh dewa Wisnu. Akhirnya guci Amerta yang berisi air suci untuk kehidupan dapat diselamatka, diangkat dan dijaga selamanya demi kehidupan damai manusia di dunia.

Cerita tersebut merupakan cerita rakyat yang tumbuh di kalangan masyarakat Malang yang bernilai edukatif tentang pentingnya kehidupan bersama yang selalu menjaga keselarasan antara alam dan manusia. Namun sayang generasi sekarang banyak yang tidak paham pada nilai-nilai yang ada pada relief candi di Malang tersebut (Sumardjo, 2016 :xiv). Keunikan bentuk relief tersebut ketika diolah ke dalam desain produk keramik, dengan cara dikreasi melalui penyederhanaan bentuk dan unsur-unsur ornamennya menjadi ornamen dekoratif yang sederhana. Ukiran ornamen tidak begitu ditonjolkan, akan tetapi dibuat lebih datar, sehingga tampilan visual dalam keramik terkesan tidak terlalu rumit. Bentuk Kendi Kamandalu yang sedang dipanggul oleh garuda dikreasi untuk difungsikan sebaga elemen estetik ruang untuk sudut interior rumah tinggal.

Berkaitan dengan pengembangan desain produk keramik Dinoyo yang bersumber pada unsur budaya lokal, tidak melepaskan aspek-aspek nilai estetik visual, simbolik, filosofis dan fungsional praktisnya. Selanjutnya bahwa nilai dari seni kerajinan hendaknya tidak merlepaskan aspek-aspek nilai sebagai kekuatan daya tarik ketika nilai lokal tersebut diolah ke dalam desain produk kerajinan. Selain itu hal yang juga penting memperhatikan prinsipprinsip desain guna mengolah bentuk dan fungsinya (Gustami Sp, 2014:71). Tugas seorang disainer tidak memberikan wacara yang rumit dan berat. Suatu produk keramik diciptakan adalah untuk dikonsumsi publik, maka bobot estetik, fungsi, dan keterjangkauan secara ekonomi harus menjadi pertimbangan ketika produk tersebut diciptakan (Irawanto, 2015:215). Mengangkat budaya lokal berupa relief Garuda Kendi Kamandalu pada candi Kidal Malang untuk direinovasi ke dalam desain keramik Dinoyo dimaksudkan agar produk keramik Dinoyo menjadi lebih beragam dan dapat diterima masyarakat di tengah perkembangan budaya global. 


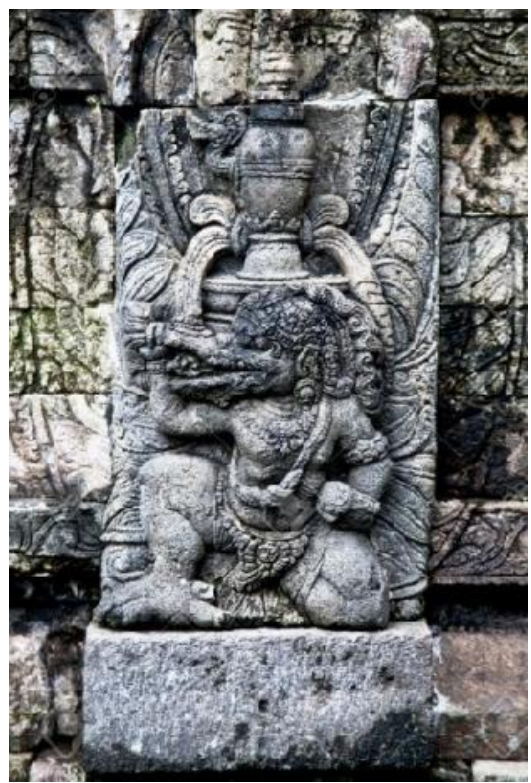

Relief Garuda Kamandalu candi Kidal di Malang propinsi Jawa Timur sebagai sumber ide pengembangan desain produk keramik.

Hasil pradesain atau gambar stetsa alternatif desain bertema " Kendi hias Garuda Kamandalu candi Kidal”.

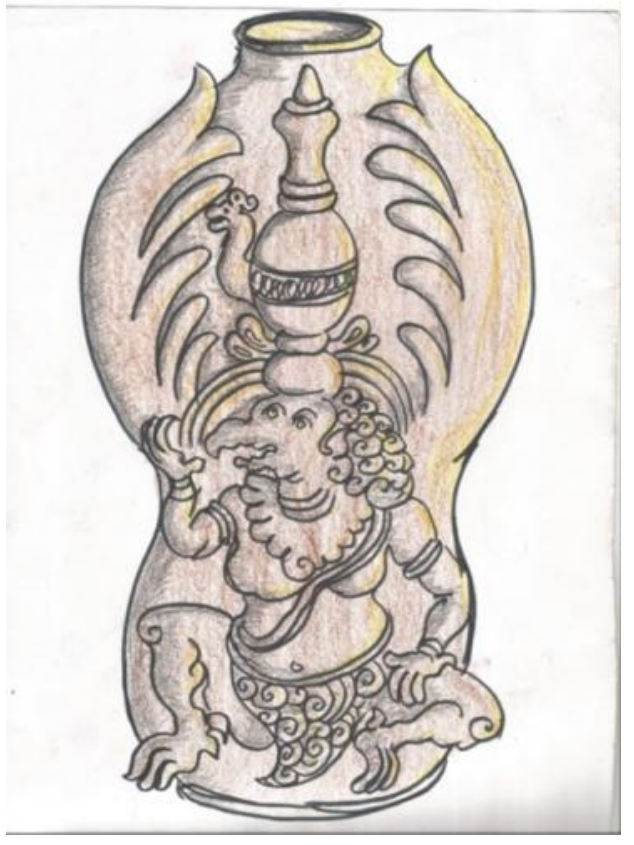

Gambar sketsa alternatif desain1

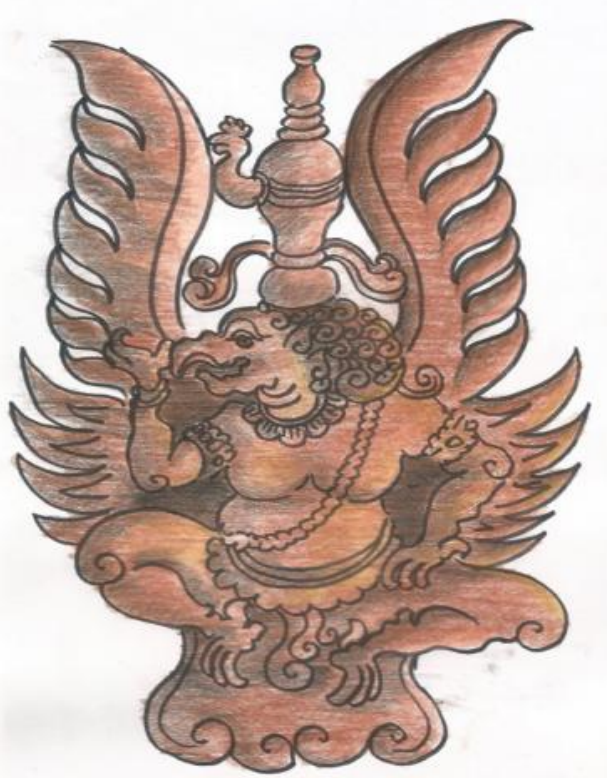

Gambar sketsa alternatif desain 2 


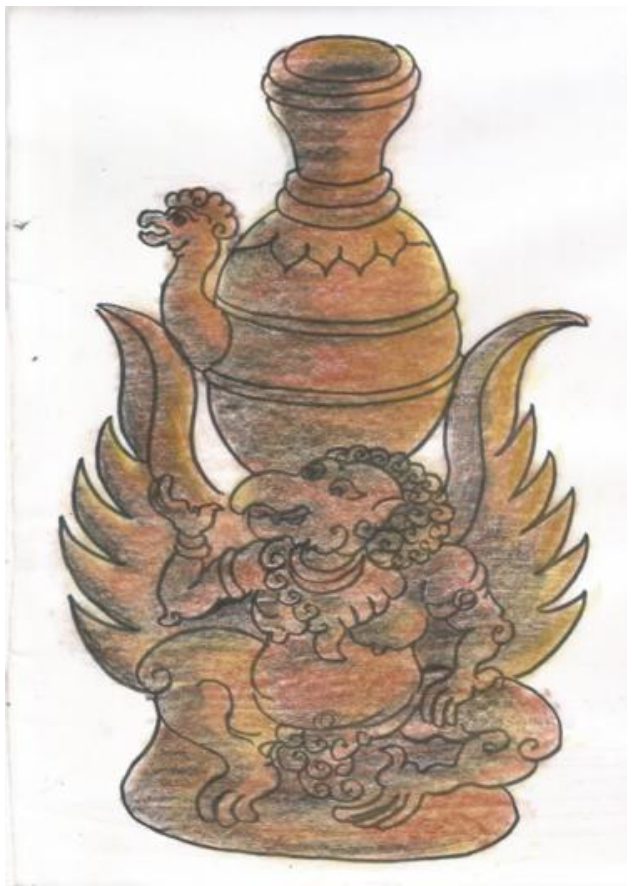

Gambar sketsa alternatif desain 3

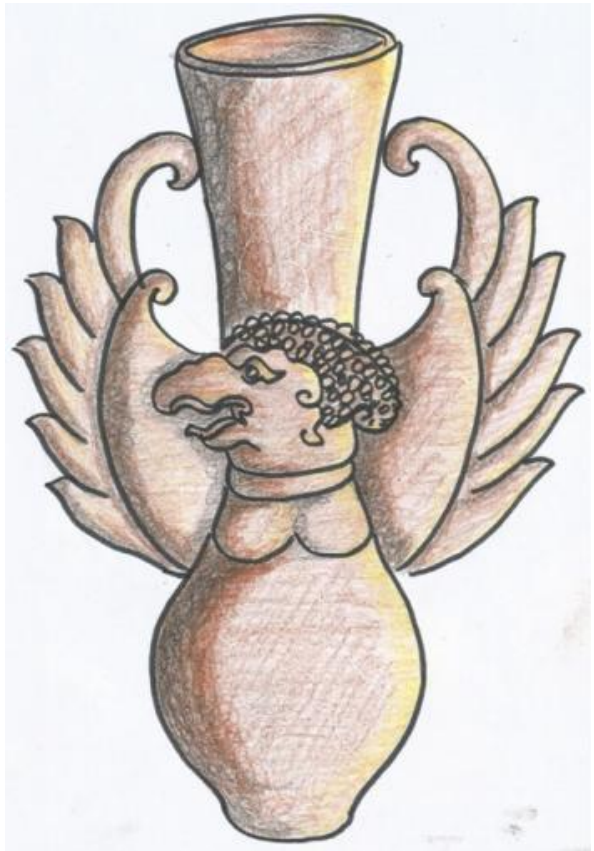

Gambar Sketsa alternatif desain 5

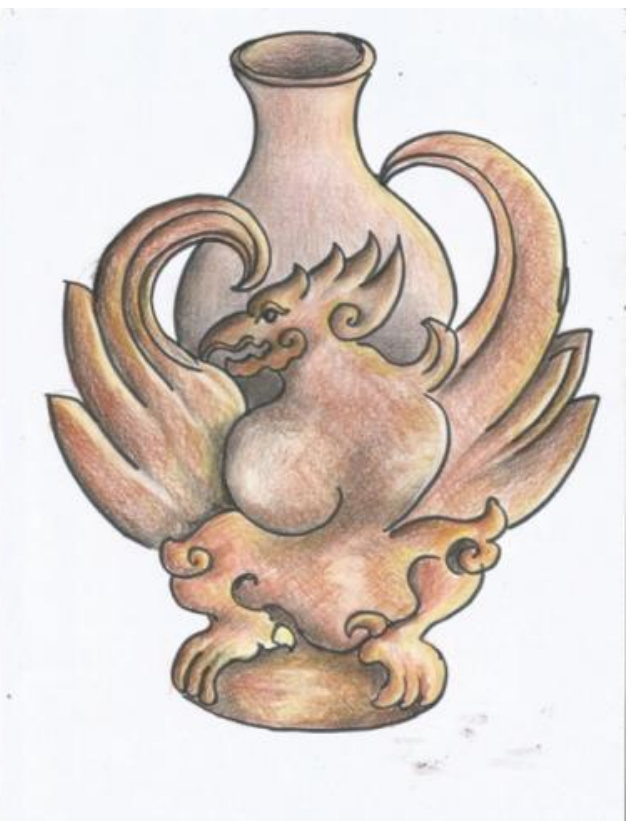

Gambar sketsa alternatif desain 4

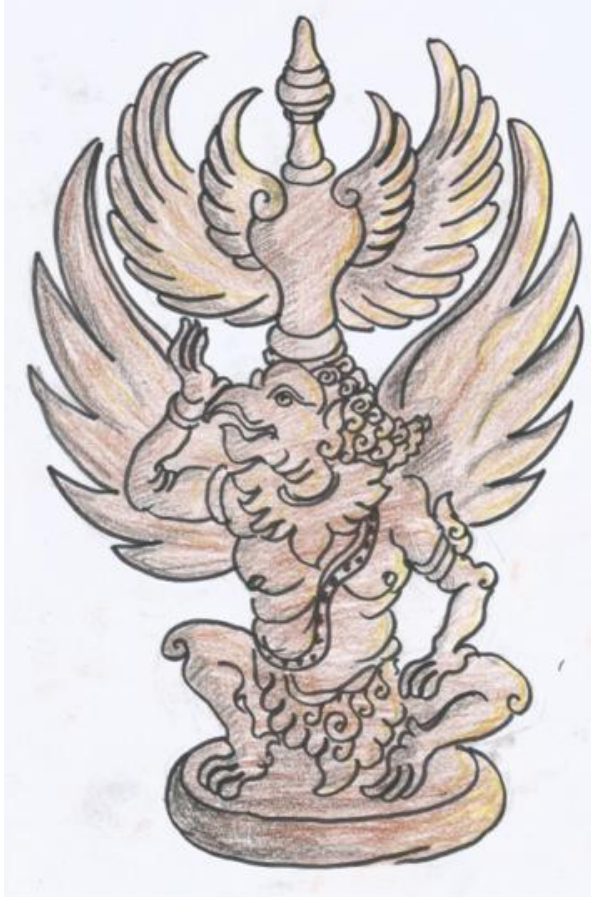

Gambar sketsa alternatif desain 6

Hasil gambar sketsa alternatif selanjutnya dipilih berdasarkan pertimbangan teknis, artistik, dan ekonomis untuk diwujudkan menjadi gambar desain. Pemilihan terhadap gambar sketsa alternatif yang berupa gambar pradesain produk keramik dilakukan dengan 
mempertimbangkan pinsip-prinsip desain serta keunikan tampilan bentuk karya (Marianto: 2015:172). Penciptaan suatu disain kerajinan harus mempertimbangkan: (a) aspek kenyamanan, yaitu jaminan tentang keamanan bagi orang yang menggunakan produk tersebut; (b) comfortable, yaitu enak digunakan sehingga produk desain produk keramik memiliki nilai praktis yang tinggi; (c) flexibility yaitu keluwesan penggunaan, dengan maksud desain produk keramik Dinoyo yaitu produk tersebut, wujudnya sesuai dengan kegunaan atau terapannya, sehingga syaratnya harus memberi kemudahan bagi penggunanya; (d) estetik, yakni terdapat nilai keunikan secara visual (Reijnders, 2005).

Gustami, Sp., (2015:77) berpandangan bahwa dalam pengembangan suatu produk keramik hias, salah satunya dengan mempertimbangkan aspek tata susun bentuk dan ornamen. Tata susun dari unsur-unsur estetik visual tersebut merupakan prinsip pengorganisasian unsur dalam desain produk. Hakekat suatu pengorganisasian yang baik adalah, jika suatu proses penyusunan unsur pendukung karya elemen-elemen dari bentuk suatu desain produk senantiasa memperhatikan prinsip-prinsip komposisi seperti: harmoni, kontras, unity, balance, simplicity, aksentuasi, dan proporsi. Prinsip dasar tersebut kadang saling terkait satu sama yang lain, sehingga sulit dipilahkan, namun kehadirannya secara eksplisit dalam pada suatu karya penyusunan akan memberikan hasil yang dapat dinikmati dan memuaskan.

\section{Pengujian Hasil Diversivikasi}

Hasil seleksi gambar sketsa alternatif yang terpilih menjadi gambar desain produk keramik dilengkapi petunjuk teknis pengerjaan. Selanjutnya hasil gambar desain yang sudah dilengkapi petunjuk teknis pengerjaan tersebut dilakukan proses uji terbatas. Proses uji terbatas ini bertujuan mendapat masukan dari pakar desain produk kerajinan. Dalam hal ini melibatkan pakar desain kriya kalangan akademisi perguruan tinggi ISI Yogyakarta, yakni saudara Timbul Raharjo (48 th) pada 27 Maret 20016.

Diversifikasi desain produk keramik dengan mempertimbangkan aspek prinsip-prinsip desain produk, diantaranya meliputi: keunikan dalam tampilan bentuk, nilai lokal, tingkat kerumitan, keharmonisan ornamen maupun bentuk, tingkat kerumitan pengerjaan, aspek kontras dalam keselarasan, keseimbangan komposisi desain secara keseluruhan, serta fungsional dan praktis (Farbstein \& Davies, 2016).

Berdasarkan evaluasi terhadap hasil diversifikasi desain produk keramik yang bersumber budaya lokal oleh pakar desain produk kriya tersebut menunjukkan bahwa desain produk tersebut dianggap layak untuk dikembangkan. Selanjutnya dapat diproduksi dan dipamerkan guna mendapat masukan dari calon pengguna produk secara lebih luas. Adapun hasil penilaian terhadap indikator hasil diversifikasi desain produk keramik dipaparkan dalam sebagai berikut:

\begin{tabular}{llllc}
\hline No & \multicolumn{1}{c}{ ASPEK YANG DINILAI } & \multicolumn{3}{c}{ SKOR } \\
\cline { 3 - 4 } & $\begin{array}{l}\text { Kurang } \\
\text { layak }\end{array}$ & $\begin{array}{l}\text { cukup } \\
\text { layak }\end{array}$ & $\begin{array}{c}\text { layak } \\
\text { layak }\end{array}$ \\
\hline 1. & $\begin{array}{l}\text { Ide tema mencerminkan nuansa } \\
\text { budaya lokal Malang. }\end{array}$ & & $\mathrm{v}$ \\
\hline 2. & $\begin{array}{l}\text { Kreativitas dalam pengolahan sumber } \\
\text { ide budaya lokal menjadi keunikan } \\
\text { bentuk dan ornamen }\end{array}$ & & $\mathrm{V}$ \\
\hline
\end{tabular}




\begin{tabular}{|c|c|c|c|c|c|}
\hline \multirow[t]{2}{*}{ No } & \multirow[t]{2}{*}{ ASPEK YANG DINILAI } & \multicolumn{4}{|c|}{ SKOR } \\
\hline & & $\begin{array}{l}\text { Kurang } \\
\text { layak }\end{array}$ & $\begin{array}{l}\text { cukup } \\
\text { layak }\end{array}$ & layak & $\begin{array}{l}\text { Sangat } \\
\text { layak }\end{array}$ \\
\hline 3 & $\begin{array}{l}\text { Keharmonisan dalam tampilan } \\
\text { komposisi elemen visual }\end{array}$ & & & & $\mathrm{v}$ \\
\hline 4. & $\begin{array}{l}\text { Kepraktisan dalam pengerjaan bentuk } \\
\text { dan raga hias, dan teknik finising } \\
\text { produk }\end{array}$ & & & $\mathrm{v}$ & \\
\hline 5. & $\begin{array}{l}\text { Kepraktisan dan kenyamanan dalam } \\
\text { kefungsian hasil produk }\end{array}$ & & & & $\mathrm{v}$ \\
\hline 6 & $\begin{array}{l}\text { Keterjangkauan konsumen terhadap } \\
\text { hasil produk }\end{array}$ & & & $\mathrm{v}$ & \\
\hline
\end{tabular}

\section{Lembar validasi hasil diversifikasi desain produk keramik hias bernuansa budaya lokal kepada ahli desain produk kriya.}

Hasil yang terbatas terhadap sketsa diverifikasi desain keramik Dinoyo tersebut adalah sebagai berikut: (1) Ide tema yang mencerminkan budaya malang memperoleh penilaian sangat layak dengan skor 4 ; (2) Kreativitas pengelolahan sumber ide budaya lokal menjadi keunikan bentuk ornamen memperoleh penilaian sangat layak dengan skor 4; (3) Memperoleh penilaian sangat layak dengan skor 4; (4) Memperoleh penilaian layak dengan skor 3; (5) Memperoleh penilaian sangat layak dengan skor 4; (6) Indikator 5 memperoleh penilaian layak dengan skor 3; sehingga dalam validasi ini skor yang diperoleh dari ahli desain produk adalah 22. Maka prosentase dari perolehan skor semua indikator tersebut adalah 92\%. Berdasarkan hasil validasai ahli desain produk kriya tersebut, maka dapat dinyatakan bahwa diversifikasi desain produk keramik hias bernuansa budaya lokal termasuk dalam kategori sangat layak untuk dikembangkan dalam prototipe produk.

Selain itu uji terbatas terhadap gambar sketsa alternatif desain produk secara terbatas juga melibatkan pelaku industri sekaligus produsen atau tokoh perajin seni kerajinan keramik Dinoyo, yakni saudara Samsul Arifin (54 th). Perajin tersebut merupakan salah satu pelaku usaha kerajinan keramik Dinoyo yang menggunakan hasil pengembangan desain produk di sentra keramik Dinoyo. Pengujian terbatas terhadap gambar desain produk dilakukan antara tanggal 12- 28 April 2016.

\begin{tabular}{lllll}
\hline No & \multicolumn{1}{c}{ ASPEK YANG DINILAI } & \multicolumn{3}{c}{ SKOR } \\
\cline { 3 - 5 } & \multicolumn{1}{c}{$\begin{array}{l}\text { Sangat } \\
\text { layak }\end{array}$} & $\begin{array}{l}\text { layak } \\
\text { cukup } \\
\text { layak }\end{array}$ & $\begin{array}{l}\text { Kurang } \\
\text { layak }\end{array}$ \\
\hline 1. & $\begin{array}{l}\text { Ide tema mencerminkan nuansa budaya } \\
\text { lokal Malang yang mencerminkan } \\
\text { keunikan bentuk dan ornamen }\end{array}$ & $\mathrm{v}$ & & \\
\hline 2. & $\begin{array}{l}\text { Kepraktisan dalam proses pembuatan } \\
\text { bentuk dan ornamen ketika } \\
\text { direproduksi dengan teknik cetak tuang } \\
\text { kombinasi cetak tekan }\end{array}$ & & $\mathrm{v}$ & \\
\hline 3. & $\begin{array}{l}\text { Kepraktisan dalam proses finihsing } \\
\text { glasir maupun non glasir }\end{array}$ & $\mathrm{v}$ & & \\
\hline
\end{tabular}




\begin{tabular}{lllll}
\hline No & \multicolumn{1}{c}{ ASPEK YANG DINILAI } & \multicolumn{3}{c}{ SKOR } \\
\cline { 3 - 5 } & $\begin{array}{l}\text { Sangat } \\
\text { layak }\end{array}$ & $\begin{array}{l}\text { layak } \\
\text { cukup } \\
\text { layak }\end{array}$ & $\begin{array}{l}\text { Kurang } \\
\text { layak }\end{array}$ \\
\hline 4. & $\begin{array}{l}\text { Kepraktisan dalam proses pengeringan } \\
\text { dan pembakaran }\end{array}$ & $\mathrm{v}$ & \\
\hline 5. & $\begin{array}{l}\text { Kepraktisan dalam pengemsan hasil } \\
\text { produk }\end{array}$ & $\mathrm{v}$ & \\
\hline 6. & $\begin{array}{l}\text { Keterjangkauan konsumen terhadap } \\
\text { hasil produk }\end{array}$ & $\mathrm{v}$ & \\
\hline
\end{tabular}

\section{Lembar evaluasi hasil diversifikasi desain produk keramik hias bernuansa budaya lokal oleh perajin sebagai pelaku kerajinan keramik Dinoyo.}

Pertanyaan yang diajukan ke ahli desain produk kriya diperoleh jawaban sebagai berikut: (1) Indikator 1 memperoleh penilaian sangat layak dengan skor 4; ( 2) Indikator 2 memperoleh penilaian layak dengan skor 3; (3) Indikator 3 memperoleh penilaian sangat layak dengan skor 4; (4) Indikator 4 memperoleh penilaian sangat layak dengan skor 4; (5) Indikator 5 memperoleh penilaian sangat layak dengan skor 4; (6) Indikator 5 memperoleh penilaian sangat layak dengan skor 4. Sehingga dalam validasi ini skor yang diperoleh dari perajin sebagai pelaku kerajinan keramik Dinoyo adalah 23. Maka prosentase dari perolehan skor semua indikator tersebut adalah 96\%. Berdasarkan hasil validasai perajin seabagi pelaku kerajinan keramik Dinoyo tersebut, maka dapat dinyatakan bahwa diversifikasi desain produk keramik hias bernuansa budaya lokal termasuk dalam kategori sangat layak untuk dikembangkan dalam prototipe produk.

Hasil pengembangan desain produk keramik telah memperoleh penilaian dari ahli desain produk kriya dan pelaku kerajinan keramik Dinoyo. Bahwa hasil pengembangan desain tersebut sangat layak untuk diwujudkan ke dalam prototipe produk, yakni menggunakan media tanah liat. Selanjutnya hasilnya dijadikan rumusan konsep pengembangan desain produk keramik Dinoyo bernuansa budaya lokal. Hasil pengembangan desain produk selanjutnya direalisasikan ke dalam bentuk prototype produk keramik. Dalam merealisasi hasil pengembangan desain dari bentuk gambar desain ke media tanah liat mengacu pada prinsip-prinsip desain. Yakni dengan mengacu pada aspek bahan, teknik pembuatan bentuk, ornamen, fungsi dan ukuran serta keunikan karakter visual.

\section{SIMPULAN}

Diversifikasi desain produk keramik di sentra keramik Dinoyo penting untuk dilakukan. hal ini untuk memenuhi tuntutan masyarakat di era perkembangan budaya global. Budaya lokal merupakan kekayaan budaya Indonesia yang tersebar di seluruh pelosok negeri. termasuk yang berada di desain lingkungan sentra kerajinan keramik Dinoyo. Bagi pengembangan produk karena itu kerajinan keramik di sentra Dinoyo hal ini penting untuk modal pengembangan produk keramik Dinoyo. diperlukan kemampuan koknetif, emosional estetik, serta kemampuan motorik untuk melakukan tersebut. Diversifikasi desain produk adalah cara meningkatkan desain produk keramik Dinoyo agar dapat meningkatkan kualitas desain produk tersebut. Peneliti telah melakukan kegiatan pengembangan desain dalam memecahkan persoalan produktivitas di setor keramik Dinoyo 
tersebut. Hal ini dilakukan dengan melakukan kajian budaya lokal yang potensial untuk dikreasi menjadi ide desain produk. Kajian tersebut dapat sebagai dasar merumuskan konsep desain dan dilanjutkan dengan melakukan proses eksplorasi bentuk desain produk serta melakukan pembuatan karya desain. Agar desain tersbut memenuh tuntutan publik konsumen, maka perlu dilakukan uji hasil pengembangan desain dengan melibatkan para pakar desain serta calon produse keramik Dinoyo, sehingga hasil pengembangan tersebut medapat masukan sebelum diterapkan ke dalam produk karya keramik yang sesungguhnya. terdapat tiga jenis budaya lokal yang telah dikembangkan menjadi ide desain produk tersebut. Yakni relief Kendi Garuda Kamandalu di candi Kidal di Malang sebagai unsur budaya lokal telah diolah menjadi desain produk keramik Dinoyo dalam bentuk ornamen maupun wujud karya keramik. Hasil pengembangan desain produk keramik tersebut diharapkan dapat diterima masyarakat di tengah perkembangan budaya global.

\section{DAFTAR RUJUKAN}

Bayindir, Nida, (at al). 2015. The need for teaching local arts as an elective course: the art of tile making in Kutahya, Procedia Social and Behaviour Sciences. 174 (2015) 2867 2874

Becker, D., 2016. 1910s Trends, in: Color Trends and Selection for Product Design. Elsevier, pp. 7-9. doi:10.1016/B978-0-323-39395-9.00002-5

Elnur Latif, Hasanow, 2015. "About Signification of Traditional Handicraft Patterns in Research of Urban Culture of Ganja" dalam Asian Journal of Social Sciences \& Humanities, vol. 4(1) Pebruary 2015, Oyama, Japan.

Farbstein, Rebecca., Davies William. 2016. Palaeolithic Ceramic Technology. The artistic origins and impacts of a technological innovation, Quaternary International, Volume 441, 1-9. DOI: 10.1016/j.quaint.2016.11.012.

Finlay, Linda. (2009). "Debating Phenomenological Research Methods" dalam J ournal Phenomenology \& Practice, Volume 3, No. 1, Open University.

Gustami, Sp., Laksmi Kusuma Wardani, Agus Heru Setiawan. 2014. Keramik Kasongan Heritage, Direktorat Pengembangan Seni Rupa, Kementerian Pariwista dan Ekonomi Kreatif, Jakarta.

Guntur. (2007). "Fenomenologi sebuah Pendekatan Alternatif dalam Penciptaan Kriya" dalam Gustami, Lanskape Tradisi Fraksi dan Desain, BP ISI Yogyakarta, Yogyakarta.

Herawati, Ida Siti, 2015. "Membangun Desain Modern Lewat Budaya Lokal Sebagai Upaya Mengembangkan Industri Kreatif Kerajinan di Kota Malang”, Dalam Proceeding Semnar Peran Strategis Seni \& Budaya dalam Membangun Kota Kreatif, Jurusan Seni dan Desain UM, 29 Oktober 2015, Malang.

Irawanto, Rudi, 2015, "Perayaan Komodifikasi Seni”, Dalam Proceeding Seminar Peran Strategis Seni \& Budaya dalam Membangun Kota Kreatif, Jurusan Seni dan Desain UM, 29 Oktober 2015, Malang.

Sony Kartika, Dharsono, (2016). Kreasi Artistik:Perjumpaan Tradisi Modern Dalam Paradigma Kekaryaan Seni. Karanganyar:Citra Sain.

Marianto, M. Dwi. (2015). Art \& Levitation: Seni dalam Cakrawala Quantum, Pohon Cahahaya, Yogyakarta.

Ponimin, 2015, “ Piggy Bank Ceramic From Dinoyo-Malang East Java Indonesia” dalam Asian Journal of Social Sciences \& Humanities Vol. 4(1) February 2015 
Rohidi, Rohendi Tjetjep. 2011, Metodologi Penelitian Seni, Cipta Prima Nusantara, Semarang

Reijnders, A., 2005. The Ceramic Process: A Manual And Source of Inspiration for Ceramic Art and Design,. A. \& C. Black, London.

Sachari, Agus, 2005. Pengantar Metodologi Budaya Rupa: Desain Arsitektur Seni Rupa dan Kriya, Erlanggga, Jakarta.

Sumardjo, Jakob, 2016. "Membaca Kembali Benda-Benda Tradisi" dalam Procededing Seminar Seni Budaya antar bangsa: Koeksistensi Seni budaya Nusantara Untuk Memperkokoh identitas Nusantara 12 Oktober 2016, Universitas Negeri Malang.

Sobur, Alex. (2013). Filsafat Komuniksi: Tradisi dan Metode Fenomenologi, Remaja Rosdakarya, Bandung.

Sabana, Setiawan. (2014). Perspektif Seni Setiawan Sabana, Garasi 10, Bandung.

Thompson, F., Hannam, K., Petrie, K., 2012. Producing Ceramic Art Works Through Tourism Research. and. Tour. Res. 39, 336-360. doi:10.1016/j.annals.2011.06.006 